\title{
Country-level land carbon sink and its causing components by the middle of the twenty-first century
}

\author{
Lifen Jiang $^{1^{*}} \mathbb{D}$, Junyi Liang ${ }^{2}$, Xingjie Lu ${ }^{3}$, Enqing Hou' ${ }^{1}$ Forrest M. Hoffman ${ }^{4}$ and Yiqi Luo ${ }^{1,5}$
}

\begin{abstract}
Background: Countries have long been making efforts by reducing greenhouse-gas emissions to mitigate climate change. In the agreements of the United Nations Framework Convention on Climate Change, involved countries have committed to reduction targets. However, carbon (C) sink and its involving processes by natural ecosystems remain difficult to quantify.
\end{abstract}

Methods: Using a transient traceability framework, we estimated country-level land C sink and its causing components by 2050 simulated by 12 Earth System Models involved in the Coupled Model Intercomparison Project Phase 5 (CMIP5) under RCP8.5.

Results: The top 20 countries with highest $C$ sink have the potential to sequester $62 \mathrm{Pg} C$ in total, among which, Russia, Canada, USA, China, and Brazil sequester the most. This C sink consists of four components: productiondriven change, turnover-driven change, change in instantaneous $C$ storage potential, and interaction between production-driven change and turnover-driven change. The four components account for $49.5 \%, 28.1 \%, 14.5 \%$, and $7.9 \%$ of the land $C$ sink, respectively.

Conclusion: The model-based estimates highlight that land C sink potentially offsets a substantial proportion of greenhouse-gas emissions, especially for countries where net primary production (NPP) likely increases substantially and inherent residence time elongates.

Keywords: Carbon sink, Carbon storage, Earth system models, Net primary productivity, Residence time, Terrestrial ecosystems

\section{Introduction}

Climate change is a big threat to the whole world. The global mean surface temperature has increased by $1.0{ }^{\circ} \mathrm{C}$ since pre-industrial levels, which is mainly caused by human activities; and the anthropogenic global warming is still ongoing at a speed of $0.2{ }^{\circ} \mathrm{C}$ per decade (IPCC 2018). Great efforts have been made by scientists and governments both nationally and internationally to adapt to and mitigate climate change. The United Nations Framework Convention on Climate Change (UNFCCC)

\footnotetext{
* Correspondence: Lifen.Jiang@nau.edu

${ }^{1}$ Center for Ecosystem Science and Society, Northern Arizona University,

Flagstaff, AZ 86011, USA

Full list of author information is available at the end of the article
}

adopted in Rio de Janeiro, Brazil in 1992, which envisaged a significant reduction in emissions of greenhouse gases (GHGs) into the atmosphere, primarily carbon dioxide $\left(\mathrm{CO}_{2}\right)$, was a historical start for the collective commitments by many countries to mitigate climate change (Akaev 2017). Following that, a big milestone was accomplished in 1997 in Kyoto, Japan, i.e., the Kyoto Protocol. In the Kyoto Protocol (https://unfccc.int/ resource/docs/convkp/kpeng.pdf), it was specified the reduction of $\mathrm{CO}_{2}$ emissions for many countries of the world. At the 21st Conference of the Parties (COP 21) to the UNFCCC, held in December of 2015 in Paris, a new climate agreement, the Paris Agreement, was adopted by many countries to replace the Kyoto

\section{Springer Open}

(c) The Author(s). 2021 Open Access This article is licensed under a Creative Commons Attribution 4.0 International License, which permits use, sharing, adaptation, distribution and reproduction in any medium or format, as long as you give appropriate credit to the original author(s) and the source, provide a link to the Creative Commons licence, and indicate if changes were made. The images or other third party material in this article are included in the article's Creative Commons licence, unless indicated otherwise in a credit line to the material. If material is not included in the article's Creative Commons licence and your intended use is not permitted by statutory regulation or exceeds the permitted use, you will need to obtain permission directly from the copyright holder. To view a copy of this licence, visit http://creativecommons.org/licenses/by/4.0/. 
Protocol after 2020 for continuous efforts to mitigate climate change. The target of the Paris Agreement is "holding the increase in the global average temperature to well below $2{ }^{\circ} \mathrm{C}$ above pre-industrial levels and pursuing efforts to limit the temperature increase to $1.5{ }^{\circ} \mathrm{C}$ above pre-industrial levels, recognizing that this would significantly reduce the risks and impacts of climate change" (https://unfccc.int/process/conferences/ pastconferences/paris-climate-change-conferencenovember-2015/paris-agreement).

Recognizing the dramatic differences in the impacts and risks for selected natural, managed, and human systems between 1.5 and $2{ }^{\circ} \mathrm{C}$ warming, the special report of IPCC (2018), Global Warming of $1.5^{\circ} \mathrm{C}$, has provided different $1.5{ }^{\circ} \mathrm{C}$-consistent emission pathways to limit warming either below $1.5{ }^{\circ} \mathrm{C}$, or returning to $1.5^{\circ} \mathrm{C}$ by around 2100 following an overshoot. These pathways, as well as those emission reductions in the Kyoto Protocol and the Paris Agreement, however, are primarily built upon a rapid phase out of $\mathrm{CO}_{2}$ emissions and deep emission reductions in other GHGs and climate forcers through broad transformations in the energy, industry, transport, buildings, Agriculture, Forestry, and Other Land-Use (AFOLU) sectors. Carbon (C) sequestered by natural terrestrial and ocean ecosystems is not well quantified to act as a critical $\mathrm{C}$ sink to offset a proportion of the anthropogenic emissions.

Indeed, natural terrestrial and ocean ecosystems can sequester substantial $\mathrm{CO}_{2}$ from the atmosphere each year. For example, the terrestrial ecosystems are estimated to take up $3.0 \pm 0.8 \mathrm{Gt} \mathrm{C}$ year $^{-1}$, approximately one-third of the $\mathrm{CO}_{2}$ emissions from fossil fuels and industry (Le Quéré et al. 2018; Friedlingstein et al. 2019). Forests can play a key role in meeting climate targets in the Paris Agreement by providing a quarter of emission reductions committed by countries and turning the globe from a net anthropogenic C source during 19902010 to a net $C$ sink by 2030 (Grassi et al. 2017). Therefore, the $\mathrm{C}$ sink from natural terrestrial and ocean ecosystems needs to be taken into account as an important component when different countries make their policies to reach net zero or negative emissions in order to limit global warming to $1.5^{\circ} \mathrm{C}$.

Scientists have long been exploring $C$ sink of the natural ecosystems both on land and in Ocean. Carbon sink of various terrestrial ecosystems has been widely studied at local or regional scale in the context of mitigating climate change (Smith et al. 2005; Tan and Lal 2005; Niu and Duiker 2006; Grelle et al. 2007; Kaul et al. 2010; Kongsager et al. 2013; Zhou et al. 2015). Carbon sequestration by terrestrial ecosystems in response to climate change in the future has also been predicted with statistical models, process-based ecosystem models, or land surface models, commonly showing a considerable global land C sink potential (Espinosa et al. 2005; Smith et al. 2005; Friedlingstein et al. 2006, 2014; Jones et al. 2013; Hararuk et al. 2014; Tan et al. 2015; Chazdon et al. 2016). However, to date, there are no such studies on land $\mathrm{C}$ sink and its causing components at the country level.

Carbon sink is usually investigated as changes in $\mathrm{C}$ storage or as flux that $\mathrm{C}$ enters into an ecosystem, often known as net ecosystem production (NEP) or net ecosystem exchange (NEE). Both changes in $\mathrm{C}$ storage or $\mathrm{C}$ influx to an ecosystem are $\mathrm{C}$ dynamics in response to external climate forcing, land use change or succession, so-called transient $\mathrm{C}$ storage or $\mathrm{C}$ flux. In terms of removing $\mathrm{CO}_{2}$ from the atmosphere in the long run, it is important that we know not only how much $\mathrm{C}$ that an ecosystem or the globe can potentially sequester, but also what component(s) dominates this $\mathrm{C}$ sink. Yet, the causing components, or in other words, the involving processes, of land $C$ sink have not been well explored. Using a linearization approach, Koven et al. (2015) separated $\mathrm{C}$ storage changes in response to doubled atmospheric $\mathrm{CO}_{2}$ of the live and dead carbon pools simulated by five Earth system models (ESMs) involved in the Coupled Model Intercomparison Project Phase 5 (CMIP5) into input-related changes, i.e., productivitydriven changes and output-related changes, i.e., turnover-driven changes. More theoretically or mechanically, transient $C$ storage of any ecosystem at a time has been quantified as the difference between instantaneous $\mathrm{C}$ storage capacity and instantaneous $\mathrm{C}$ storage potential by Luo et al. (2017). In detail, C storage capacity is the maximum amount of $\mathrm{C}$ that an ecosystem can store at any given time and it is the product of net primary production (NPP) and $\mathrm{C}$ residence time. Instantaneous carbon storage potential represents the internal capability of an ecosystem to equilibrate the current $C$ storage with the $\mathrm{C}$ storage capacity. It indicates a potential of an ecosystem to store additional $\mathrm{C}$ when it has a positive value or a potential to lose $\mathrm{C}$ when the value is negative at a given time. This new framework that decomposes transient $C$ storage into instantaneous $C$ storage capacity and instantaneous $\mathrm{C}$ storage potential has an advantage over the traditional ways in investigating dynamics of $C$ storage because it takes into account the inherent characteristics of an ecosystem, such as NPP and C residence time. NPP and $C$ residence time are the most important components that dominate uncertainty in terrestrial vegetation and soil $\mathrm{C}$ responses to climate and atmospheric $\mathrm{CO}_{2}$ (Todd-Brown et al. 2013; Friend et al. 2013; Jiang et al. 2015).

The theory of transient $\mathrm{C}$ storage developed by Luo et al. (2017) has been applied to explore the mechanisms behind the dynamic of the transient $\mathrm{C}$ storage in response to climate change among different ecosystems 
(Jiang et al. 2017) or among different ESMs (Zhou et al. 2018). In this study, we analyzed model output of 12 ESMs involved in CMIP5 based on this theoretical decomposition of transient $\mathrm{C}$ storage. The objective is to quantify the land $\mathrm{C}$ sink and its causing components of different countries by the middle of the twenty-first century under the most severe climate change scenario with a new framework and therefore, to help policy makers to better mitigate climate change.

\section{Materials and methods}

The transient traceability framework for carbon storage dynamics

In this study, land $C$ sink of different countries by 2050 was explored with a transient traceability framework for $\mathrm{C}$ storage dynamics with CMIP5 model output. Carbon sink refers to the difference in $\mathrm{C}$ storage between two time steps, i.e., year 2050 (average of 2046-20250) and year 2005 (average of 2001-2005), respectively.

The transient traceability framework for $\mathrm{C}$ storage dynamics was first theoretically analyzed by Luo et al. (2017) based on the fact that most land C cycling models shared some common properties. It was then applied to two forest ecosystems to trace the different responses of C storage to climate change and to reveal the mechanisms underlying the different responses (Jiang et al. 2017). In this traceability framework, transient $C$ storage at a certain time is jointly determined by instantaneous $\mathrm{C}$ storage capacity and instantaneous $\mathrm{C}$ storage potential as expressed by the following equation:

$$
X(t)=X_{c}(t)-X_{p}(t)
$$

where $X(t)$ is transient C storage; $X_{c}$ is $C$ storage capacity, which is defined as the maximum instantaneous $C$ storage without any environmental or other restrictions at a given time; and $X_{p}$ is instantaneous $C$ storage potential, which represents the unrealized $C$ storage due to environmental or other limitations at a given time.

Furthermore, C storage capacity, $X_{c}$, is co-determined by $C$ input (gross $\mathrm{fv}, \tau(t)$, as shown in the following equation:

$$
X_{c}(t)=N P P(t) \times \tau(t)
$$

And instantaneous $C$ storage potential, $X_{p}$, is a product of net $C$ pool change, $X^{\prime}(t)$, and chasing time. Chasing time measures the time needed for net $C$ pool change to be redistributed in the network with all $\mathrm{C}$ pools, which is not further explored in this analysis.

\section{CMIP5 model output}

We used model output of historical simulations and representative concentration pathway (RCP) 8.5 of 12 ESMs in CMIP5, including bcc-csm1-1-m, BNU-ESM,
CanESM2, CESM1-BGC, GFDL-ESM2G, HadGEM2-ES, inmcm4, IPSL-CM5A-LR, MIROC-ESM, MPI-ESM-LR, MRI-ESM1, and NorESM1-ME. Details of these ESMs were given in Table 1. RCP8.5 represents the most severe climate change scenario among all scenarios. We downloaded model output of monthly $\mathrm{C}$ mass in all land $\mathrm{C}$ pools, including $\mathrm{C}$ in vegetation (variable "cVeg"), course wood debris (variable "cCwd"), litter (variable "cLitter"), and soil (variable "cSoil"). Carbon pools were then added together to get ecosystem C. Monthly NPP (variable "npp") was also downloaded for decomposition of land $\mathrm{C}$ sink. For the inmcm4 model, we calculated its npp as the difference between GPP (variable "gpp") and autotrophic respiration (variable "ra") because this model did not have direct output of npp. Monthly $\mathrm{C}$ pools and NPP were converted to yearly data. In addition, land area fraction (variable "sftlf") of each model was used for computing carbon storage and NPP of different countries.

For each model, we used the ensemble member r1i1p1 as it is the only ensemble available for all CMIP5 models. In addition, a previous study has demonstrated that simulations among the multiple ensembles from a single model were similar in general (Jiang et al. 2015). The letters "r," "i," and "p" in the ensemble name indicate the initial condition, initialization method and perturbed physics version, respectively and " 1 " after each letter is the realization number for the respective parameter (Taylor et al. 2010, 2012).

We analyzed land C sink of 12 ESMs at both grid level and country level and decomposed the land $C$ sink into four components at country level as described in the next section. Land $C$ sink was calculated as the $C$ storage difference between year 2050 (average of 20462050) of RCP8.5 and year 2005 (average of 2001-2005) of historical runs. The country border map we used was from WorldClim (http://www.worldclim.org). Because the original resolutions of CMIP5 model outputs were different from one another (Table 1) and were also different with the country border map, we regridded $C$ density and NPP of model outputs to match the resolution of the country border map using conservation of mass.

\section{Application of the transient traceability framework to CMIP5 model outputs}

Land $\mathrm{C}$ sink, i.e., the difference in $\mathrm{C}$ storage between two time steps, $\Delta X$, can be achieved by the following equation according to Eq. 1:

$$
\Delta X=\Delta X_{c}-\Delta X_{p}
$$

Change of $C$ storage capacity $\left(\Delta X_{c}\right)$ is equal to: 
Table 1 Summary of CMIP5 ESMs and their land carbon cycle components

\begin{tabular}{|c|c|c|c|c|c|c|c|c|c|}
\hline $\begin{array}{l}\text { Model name } \\
\text { of ESMs }\end{array}$ & Version & Modeling group & $\begin{array}{l}\text { Land carbon } \\
\text { cycle } \\
\text { components }\end{array}$ & $\begin{array}{l}\text { Number } \\
\text { of plant } \\
\text { functional } \\
\text { types }\end{array}$ & $\begin{array}{l}\text { Number } \\
\text { of live } \\
\text { carbon } \\
\text { pools }\end{array}$ & $\begin{array}{l}\text { Dynamic } \\
\text { vegetation }\end{array}$ & $\begin{array}{l}\text { Nitrogen } \\
\text { cycle }\end{array}$ & $\begin{array}{l}\text { Original } \\
\text { resolution } \\
\text { of latitude } \\
\text { and } \\
\text { longitude } \\
\left({ }^{\circ} \text { lat } \times^{\circ} \text { lon }\right)\end{array}$ & References \\
\hline BCC-CSM1.1 & 20120918 & $\begin{array}{l}\text { Beijing Climate Center, } \\
\text { China Meteorological } \\
\text { Administration }\end{array}$ & BCC-AVIM1.0 & 15 & 3 & No & No & $2.81 \times 2.81$ & $\begin{array}{l}\text { Ji et al. 2008; } \\
\text { Wu et al. } 2013\end{array}$ \\
\hline BNU-ESM & 20120504 & $\begin{array}{l}\text { College of Global Change } \\
\text { and Earth System Science, } \\
\text { Beijing Normal University }\end{array}$ & $\begin{array}{l}\text { CoLM+BNUDGVM } \\
\text { (based on LPJ) }\end{array}$ & 10 & 4 & Yes & No & $2.81 \times 2.81$ & $\begin{array}{l}\text { Dai et al. 2003, } \\
\text { 2004; Ji et al. } \\
2014\end{array}$ \\
\hline CanESM2 & 20120410 & $\begin{array}{l}\text { Canadian Centre for } \\
\text { Climate Modeling and } \\
\text { Analysis }\end{array}$ & CLASS2.7+CTEM1 & 9 & 3 & No & No & $2.81 \times 2.81$ & $\begin{array}{l}\text { Arora and } \\
\text { Boer. } 2010\end{array}$ \\
\hline CESM1-BGC & 20121029 & $\begin{array}{l}\text { Community Earth System } \\
\text { Model Contributors }\end{array}$ & CLM4 & 15 & 4 & No & Yes & $0.94 \times 1.25$ & $\begin{array}{l}\text { Thornton and } \\
\text { Zimmermann } \\
\text { 2007; Thornton } \\
\text { et al. 2007, } \\
\text { 2009; Lawrence } \\
\text { et al. } 2011\end{array}$ \\
\hline GFDL-ESM2G & 20121206 & $\begin{array}{l}\text { Geophysical Fluid } \\
\text { Dynamics Laboratory }\end{array}$ & LM3 & 5 & 5 & Yes & No & $1.99 \times 2.48$ & $\begin{array}{l}\text { Shevliakova } \\
\text { et al. 2009; } \\
\text { Dunne et al. } \\
2013\end{array}$ \\
\hline HadGEM2-ES & 20111007 & Met Office Hadley Centre & TRIFFID & 5 & 3 & Yes & No & $1.24 \times 1.88$ & $\begin{array}{l}\text { Cox 2001; } \\
\text { Collins et al. } \\
\text { 2011; Jones } \\
\text { et al. 2011; The } \\
\text { HadGEM2 } \\
\text { Development } \\
\text { Team 2011 }\end{array}$ \\
\hline INM-CM4 & 20110323 & $\begin{array}{l}\text { Institute for Numerical } \\
\text { Mathematics }\end{array}$ & LSM 1.0 & 12 & 3 & No & No & $1.50 \times 2.00$ & $\begin{array}{l}\text { Bonan 1996; } \\
\text { Volodin } 2007\end{array}$ \\
\hline IPSL-CM5A-MR & 20120430 & $\begin{array}{l}\text { Institut Pierre Simon } \\
\text { Laplace }\end{array}$ & ORCHIDEE & 12 & 8 & No & No & $1.26 \times 2.50$ & $\begin{array}{l}\text { Dufresne et al. } \\
\text { 2013; Krinner } \\
\text { et al. } 2005\end{array}$ \\
\hline MIROC-ESM & 20120710 & $\begin{array}{l}\text { Japan Agency for Marine- } \\
\text { Earth Science and } \\
\text { Technology, Atmosphere } \\
\text { and Ocean Research } \\
\text { Institute (The University of } \\
\text { Tokyo), and National } \\
\text { Institute for Environmental } \\
\text { Studies }\end{array}$ & $\begin{array}{l}\text { MATSIRO+SEIB- } \\
\text { DGVM }\end{array}$ & 13 & 4 & Yes & No & $2.81 \times 2.81$ & $\begin{array}{l}\text { Sato et al. } \\
\text { 2007; } \\
\text { Watanabe et al. } \\
2011\end{array}$ \\
\hline MPI-ESM-MR & 20120503 & $\begin{array}{l}\text { Max Planck Institute for } \\
\text { Meteorology }\end{array}$ & JSBACH & 12 & 3 & Yes & No & $1.88 \times 1.88$ & $\begin{array}{l}\text { Raddatz et al. } \\
\text { 2007; Brovkin } \\
\text { et al. 2009; } \\
\text { Reick et al. } \\
2013\end{array}$ \\
\hline MRI-ESM1 & 20130307 & $\begin{array}{l}\text { Meteorological Research } \\
\text { Institute }\end{array}$ & $\begin{array}{l}\text { Models of the } \\
\text { biochemical } \\
\text { photosynthesis } \\
\text { processes at leaf } \\
\text { level and LPJ- } \\
\text { DGVM at } \\
\text { ecosystem level }\end{array}$ & 10 & 3 & Yes & No & $1.00 \times 0.50$ & $\begin{array}{l}\text { Adachi et al. } \\
2013\end{array}$ \\
\hline NorESM1-ME & 20120225 & Norwegian Climate Centre & CLM4 & 15 & 4 & No & Yes & $1.88 \times 2.50$ & $\begin{array}{l}\text { Tjiputra et al. } \\
2013\end{array}$ \\
\hline
\end{tabular}




$$
\Delta X_{c}=\mathrm{NPP}_{1} \times \tau_{1}-\mathrm{NPP}_{0} \times \tau_{0}
$$

where $\mathrm{NPP}_{1}$ and $\tau_{1}$ are NPP and $\tau$ at time step 2 , respectively, which is year 2050 in this study; and $\mathrm{NPP}_{0}$ and $\tau_{0}$ are NPP and $\tau$ at time step 1 (i.e., year 2005), respectively.

If we add and then minus a term, $\mathrm{NPP}_{1} \times \tau_{0}$, which does not change the equation, equation 4 becomes:

$$
\begin{aligned}
\Delta X_{c}= & \mathrm{NPP}_{1} \times \tau_{1}-\mathrm{NPP}_{1} \times \tau_{0}+\mathrm{NPP}_{1} \\
& \times \tau_{0}-\mathrm{NPP}_{0} \times \tau_{0}
\end{aligned}
$$

Because the term " $\tau_{1}-\tau_{0}$ " is actually the change of $\tau(\Delta \tau)$, and similarly, the term "NPP ${ }_{1}-\mathrm{NPP}_{0}$ " means the change of NPP $(\triangle \mathrm{NPP})$, equation 5 can be changed to:

$$
\Delta X_{c}=\Delta \tau \times \mathrm{NPP}_{1}+\Delta \mathrm{NPP} \times \tau_{0}
$$

As explained above, $\mathrm{NPP}_{1}$ is sum of $\mathrm{NPP}_{0}$ and the change of NPP $(\triangle \mathrm{NPP})$, so equation 6 can be written as:

$$
\Delta X_{c}=\Delta \tau \times\left(\mathrm{NPP}_{0}+\Delta \mathrm{NPP}\right)+\Delta \mathrm{NPP} \times \tau_{0}
$$

And Eq. 7 can be reorganized into the following format:

$$
\Delta X_{c}=\Delta \mathrm{NPP} \times \tau_{0}+\Delta \tau \times \mathrm{NPP}_{0}+\Delta \mathrm{NPP} \times \Delta \tau
$$

Combining Eqs. 3 and 8, we get the equation for deriving $C$ sink $(\Delta X)$ :

$$
\begin{aligned}
\Delta X= & \Delta \mathrm{NPP} \times \tau_{0}+\Delta \tau \times \mathrm{NPP}_{0}+\Delta \mathrm{NPP} \\
& \times \Delta \tau-\Delta X_{p}
\end{aligned}
$$

With Eq. 9, we can trace land $C$ sink into four components, i.e., production-driven change $\left(\Delta \mathrm{NPP} \times \tau_{0}\right)$, turnover-driven change $\left(\Delta \tau \times \mathrm{NPP}_{0}\right)$, interaction between production-driven change and turnover-driven change $(\Delta \mathrm{NPP} \times \Delta \tau)$, and change in instantaneous $\mathrm{C}$ storage potential $\left(\Delta X_{p}\right)$. Initial NPP and initial $\tau$ here represent values of NPP and $\tau$ at time step 1, i.e., year 2005 in specific. In this study, we calculated $\tau$ and $X_{p}$ using the method adopted by Zhou et al. (2018):

$$
\begin{aligned}
& \tau=\frac{X}{N P P-X^{\prime}} \\
& X_{p}(t)=X_{c}(t)-X(t)
\end{aligned}
$$

We calculated yearly $X^{\prime}, \tau, X_{c}$, and $X_{p}$ at both grid level and country level. For both levels, we averaged results from 2001 to 2005 to represent year 2005 and the results from 2046 to 2050 to represent year 2050. At grid level, we excluded $\tau$ greater than 500 years before outputting the results because most previous studies have shown that global averaged ecosystem residence time is much less than 100 years (Carvalhais et al. 2014; $\mathrm{Lu}$ et al. 2018; Wu et al. 2020). At country scale, we first regridded ecosystem C and NPP of each model to the resolution of the country border map after multiplying by land area fraction. Then we could calculate ecosystem C storage and NPP of countries. After that, $X^{\prime}, \tau, X_{c}$, and $X_{p}$ of countries for each model were calculated. Within each model, if a country had 0 or missing values in ecosystem $\mathrm{C}$ and/or NPP in 3-5 years, we excluded that country. In contrast, if a county had 0 or missing values in ecosystem $C$ and/or NPP in only 1-2 years, we kept that country, but removed all variables for that year(s). The same processing was made for a country with $\tau$ that was $<0$ or $>500$ years. Finally, for each country, we reported results from multiple model means. If a country had either "0" or missing values in any of the variables, including ecosystem $C$ storage, NPP, $\tau, X_{c}$, and $X_{p}$ in more than 6 models, we did not include that country. The validations of derived land $\mathrm{C}$ sink of top 20 countries were provided in Fig. 1.

The calculations of the yearly average of $\mathrm{C}$ pools and NPP of model outputs, regridding of C pools and NPP of model outputs, and sums of C and NPP for countries were performed with the NCAR Command Language (Version 6.6.2, 2019).

\section{Results}

\section{Global distribution of land carbon sink}

The global distribution of land $C$ sink shows that most area on Earth will gain $C$ in terrestrial ecosystems under RCP8.5 by the middle of the twenty-first century (Fig. 2). As for the magnitude of C sink, BNU-ESM, HadGEM2ES, IPSL-CM5A-LR, and MRI-ESM1 predict higher land C sink that other models. Moreover, most ESMs predict that tropical and tundra regions will gain more $C$ than other regions. MRI-ESM1 also predicts greater $\mathrm{C}$ sink in northern America and Europe. On the contrary, two ESMs with nitrogen (N) coupled, CESM1-BGC and NorESM1-ME, simulate substantial C loss in tropical region. The $\mathrm{C}$ sink in these two models in other regions are also substantially lower than other models.

\section{Land carbon sink of top 20 countries}

Unlike the grid level, at the country level, we report results of average land $\mathrm{C}$ sink across all CMIP5 models. Land $\mathrm{C}$ sink by the middle of the twenty-first century of the top 20 countries is shown in Fig. 3. Total land $\mathrm{C}$ sequestered by these 20 countries during 45 years from 2005 to 2050 is $62.1 \mathrm{Pg} \mathrm{C}$. Among them, Russia, Canada, USA, China, and Brazil sequester the most, gaining $C$ of 19.6, 10.4, 9.6, 4.5, and 2.7 $\mathrm{Pg} C$, respectively. These five countries collectively contribute three quarters of the total $\mathrm{C}$ sequestrated by the top 20 countries, with Russia sequestering about one third of the total $\mathrm{C}$ sink by these 20 countries. However, the rest 15 countries each only gain $\mathrm{C}$ less than $2.7 \mathrm{Pg} \mathrm{C}$. 

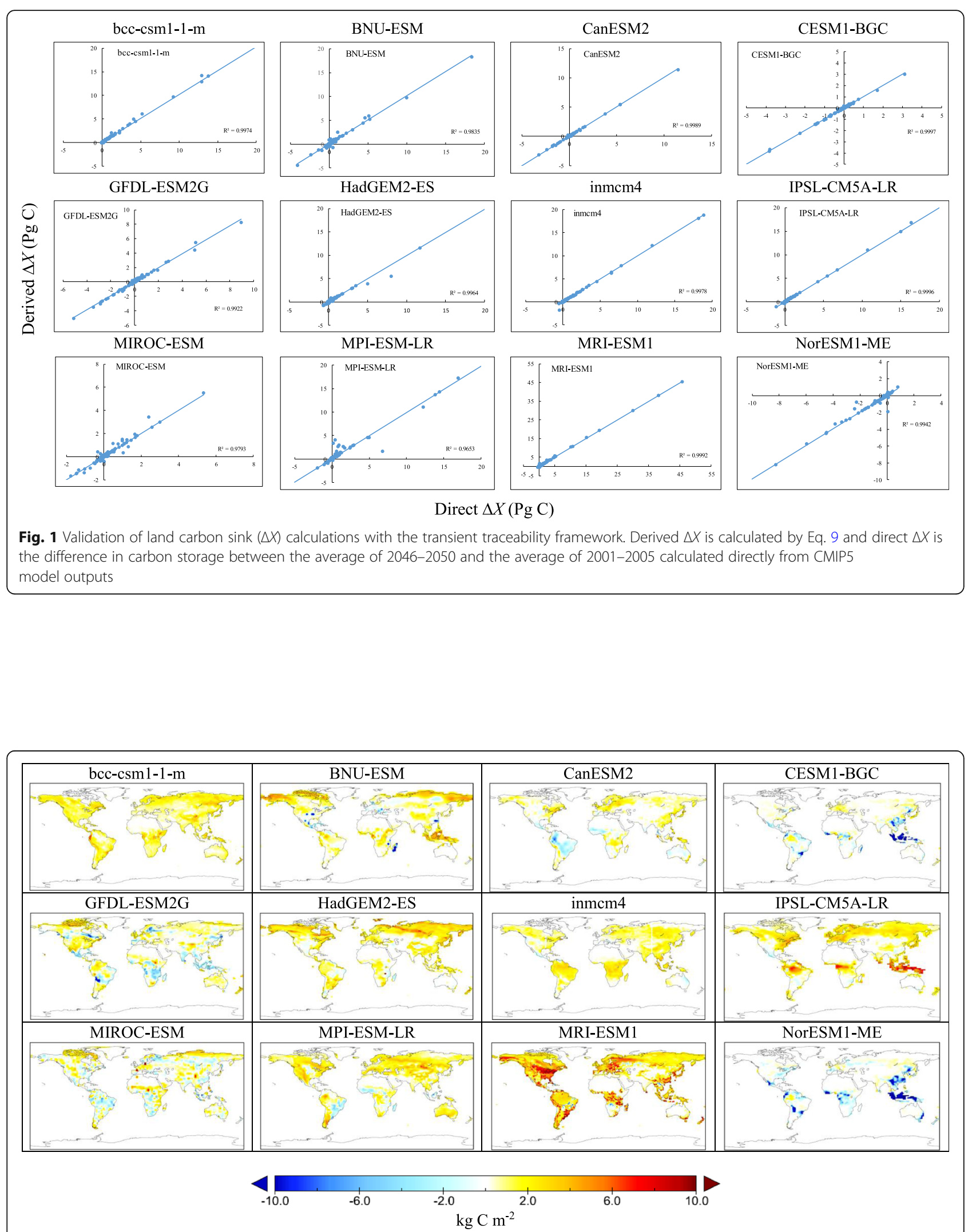

Fig. 2 Global maps of land carbon sink by the middle of the 21st century. Shown is cumulative carbon sink by 12 ESMs in CMIP5 over the period from 2005 (average of 2001-2005) to 2050 (average of 2046-2050) under RCP8.5 


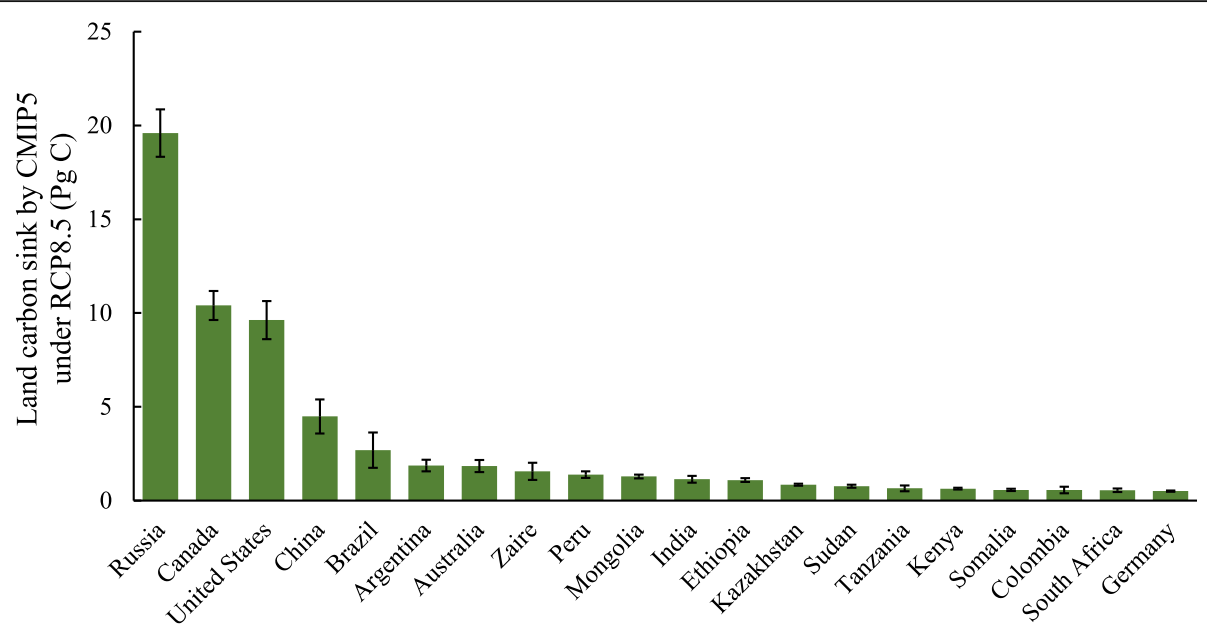

Fig. 3 Land carbon sink by the middle of the 21st century of top 20 countries by 12 ESMs in CMIP5 under RCP 8.5 (model means \pm SE). Shown is cumulative carbon sink over the period from 2005 (average of 2001-2005) to 2050 (average of 2046-2050)

\section{Attributions of land carbon sink to its causing components}

According to the transient traceability framework, land C sink can be decomposed into four components: (1) production-driven change, (2) turnover-driven change, (3) interaction between production-driven change and turnover-driven change, and (4) the change in instantaneous $\mathrm{C}$ storage potential. Based on the results of averages across all models, in the four components, productiondriven change accounts for the largest proportion, approximately half (49.5\%), of the C sink (Fig. 4), followed by turnover-driven change (28.1\%), and then the change in instantaneous C storage potential (14.5\%). The interaction between production-driven change and turnoverdriven change contributes the least to $\mathrm{C}$ sink (7.9\%).

\section{Discussion}

Spatial distribution of land carbon sink under the most severe climate change scenario

While there is some uncertainty in simulated land $\mathrm{C}$ sink by the CMIP5 models, it is also convergent that terrestrial ecosystems will serve as $\mathrm{C}$ sink over the next 30 years in most of the regions on lands as shown in Fig. 2. The two regions that have higher $C$ sink are tropics and tundra, which is also agreed among the models except for the two ESMs with $\mathrm{N}$ cycle (CESM1-BGC and NorESM1-ME), in which tropical region will lose C.

Carbon sink of various vegetation types has been investigated at local to regional scales mostly from the perspective of land use change and land use management for mitigating climate change. For example, willow

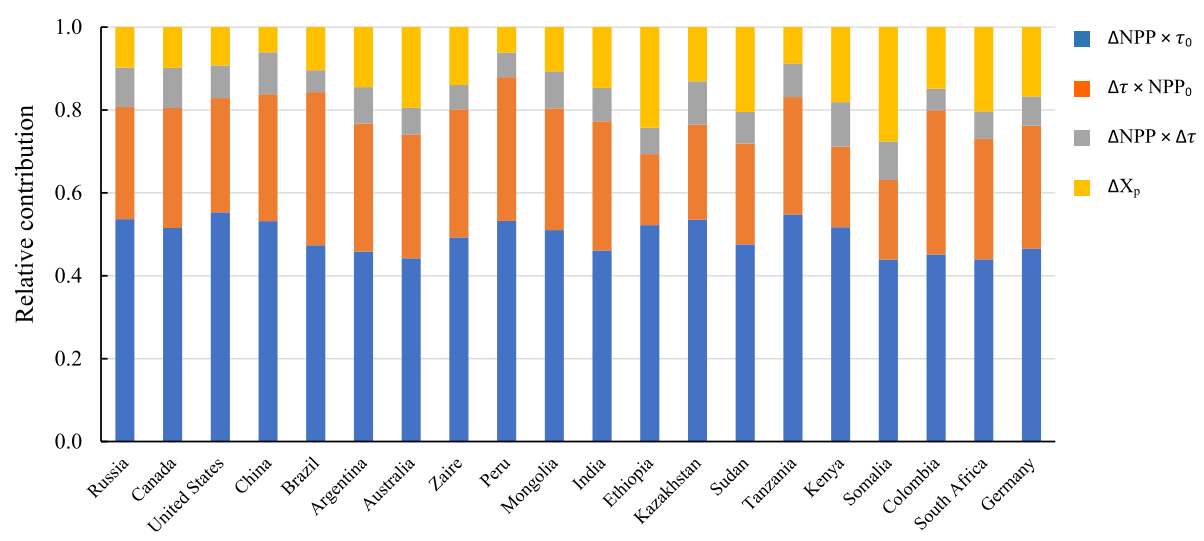

Fig. 4 Contributions of each component to cumulative land carbon sink by the middle of the twenty-first century of top 20 countries by 12 ESMs in CMIP5 under RCP 8.5. The four components of land $C$ sink are: production-driven change $\left(\triangle N P P \times \tau_{0}\right)$, turnover-driven change $\left(\triangle T \times N P P_{0}\right)$, interaction between production-driven change and turnover-driven change $(\triangle N P P \times \Delta T)$, and change in instantaneous $C$ storage potential $\left(\Delta X_{p}\right)$. $N P P_{0}$ and $\tau_{0}$ represent NPP and $\tau$ in year 2005 (average of 2001-2005), respectively. $\Delta N P P, \Delta \tau$, and $\Delta X_{p}$ represent changes of NPP, $\tau$, and $X_{p}$ between 2050 and 2005 (i.e., average of 2046-2050 minus average of 2001-2005), respectively. NPP: net primary production, $\tau$ : C residence time, $X_{\mathrm{p}}$ : instantaneous $\mathrm{C}$ storage potential 
plantation in central Sweden was a sink of ca. 8 ton C $\mathrm{ha}^{-1}$ year ${ }^{-1}$, about half of which was attributed to fertilization (Grelle et al. 2007). In Ohio, USA, sequestration rate of soil organic $\mathrm{C}$ was estimated to be $62 \mathrm{~g} \mathrm{C}$ $\mathrm{m}^{-2}$ year $^{-1}$ with conversion from conservation tillage to no-till for cultivated Alfisols, and the reforestation of cropland could increase $71 \mathrm{Tg} \mathrm{C}$ in 25 years (Tan and Lal 2005). The sequestration potential capacity by afforestation of marginal agricultural land in the Midwestern United State was quantified to be $508-540 \mathrm{Tg} C$ over 20 years and 1018-1080 Tg $C$ over 50 years, which would offset $6-8 \%$ of $\mathrm{CO}_{2}$ emissions by combustion of fossil fuel in that region (Niu and Duiker 2006). Among the four major plantation crops in tropics, the rubber plantations had much higher $C$ sequestration potential (214 ton $\mathrm{C} \mathrm{ha}^{-1}$ ) than Cocoa $\left(65\right.$ ton $\mathrm{C} \mathrm{ha}^{-1}$ ), orange (76 ton $\mathrm{C} \mathrm{ha}^{-1}$ ), and oil palm (45 ton $\mathrm{C} \mathrm{ha}^{-1}$ ) plantations (Kongsager et al. 2013). Second-growth forests in the Latin American tropics could potentially accumulate $8.48 \mathrm{Pg}$ $\mathrm{C}$ in aboveground biomass over four decades, corresponding to a total sequestration of $31.09 \mathrm{Pg} \mathrm{CO}_{2}$ and equivalent to $\mathrm{C}$ emissions from fossil fuels and industry by all of Latin America and the Caribbean from 1993 to 2014 (Chazdon et al. 2016).

Globally, most of land C models simulated C sink over the simulation period from 1959 to 2010 (Huntzinger et al. 2017). Cumulative net land $C$ sink was mainly contributed by $\mathrm{CO}_{2}$ fertilization and $\mathrm{N}$ deposition, whereas climate and land cover change caused $\mathrm{C}$ loss from land in most of the models (Huntzinger et al. 2017). For tropic region, climate had a negative effect on land $C$ sequestration, but in northern mid-latitude and arctic-boreal region, it stimulated $\mathrm{C}$ sequestration (Huntzinger et al. 2017). Multimodel mean of CMIP5 ESMs showed that land lost 19 Pg C from 1850 to 2005 but with a very wide range across models rooted from the strength of the $\mathrm{CO}_{2}$ fertilization effect and differences in model's implementation of land use change (Jones et al. 2013). However, these models agreed with each other much better on the direction of net land $\mathrm{C}$ change in the future; and most of the models predicted a land $\mathrm{C}$ sink under four future representative concentration pathways although the magnitude was different among the models (Jones et al. 2013). Similarly, while all eleven coupled climate-carbon cycle models in the $\mathrm{C}^{4} \mathrm{MIP}$ simulated a negative sensitivity for land $\mathrm{C}$ cycle to future climate, land will remain as a $\mathrm{C}$ sink by 2100 but with a declining magnitude dominated by the reduction of land $\mathrm{C}$ uptake in tropics (Friedlingstein et al. 2006).

However, sharing the same land $\mathrm{C}$ model (the Community Land Model, CLM4) and having nitrogen cycle incorporated (Thornton et al. 2009), CESM1-BGC and NorESM1-ME simulate a significant $C$ loss in tropical and tundra regions. The $\mathrm{C}$ loss is a result of the limited response to increasing atmospheric $\mathrm{CO}_{2}$ concentration
(Friedlingstein et al. 2014) due to the down regulation by $\mathrm{N}$ on photosynthesis (Luo et al. 2004; Friend et al. 2013; Jiang et al. 2015).

\section{Land carbon sink of different countries under the most severe climate change scenario}

Among the top 20 countries with higher land $\mathrm{C}$ sink by the middle of the twenty-first century, Russia, Canada, USA, China, and Brazil sequester the most (Fig. 3), which is not surprising in terms of area or location of the countries. These top 20 countries will sequester a substantial amount of $\mathrm{C}(62.1 \mathrm{Pg} \mathrm{C})$ in their terrestrial ecosystems even under the most severe climate scenario, RCP8.5.

Government policies can have significant effects on anthropogenic GHG emissions. For example, a 17\% reduction in daily global $\mathrm{CO}_{2}$ emissions during the COVID-19 forced confinement has been reported, with half of reduction resulting from changes in surface transport (Le Quéré et al. 2020). In order to mitigate climate change, countries in the world have long been engaged in efforts to reduce anthropogenic emissions by adopting appropriate policies. In the protocols and agreements envisaged under UNFCCC, many countries have committed to reduce their emissions from fossil fuels and industry with a clear target. However, in these protocols and agreements, $\mathrm{C}$ sink by natural ecosystems and its causing components are not well quantified to offset some of the anthropogenic emissions. Globally, anthropogenic $\mathrm{CO}_{2}$ emissions from fossil fuels and industry have reached to an average of $9.5 \mathrm{GtC}_{\text {year }}{ }^{-1}$ during 2009-2018 (Friedlingstein et al. 2019). China, USA, European Union, and India are the top emitters and collectively account for $59 \%$ of global fossil $\mathrm{CO}_{2}$ emissions (Friedlingstein et al. 2019).

Land has acted as $\mathrm{C}$ sink historically (Huntzinger et al. 2017) and has taken up about one third of fossil $\mathrm{CO}_{2}$ emissions (Friedlingstein et al. 2019). Land may keep sequestering $\mathrm{C}$ from atmosphere until 2100 as simulated by 8 out of 11 CMIP 5 models, but the strength of land $C$ sink becomes weaker and weaker toward the end of the simulation period of 2100 (Friedlingstein et al. 2014). Fully coupled ESMs under the 1 pct $\mathrm{CO}_{2}$ experiment in CMIP6 also simulate land $\mathrm{C}$ sink although the increase of sink declines as terrestrial $\mathrm{CO}_{2}$ fertilization effect saturates and the respiratory losses increase as a result of built-up C pools (Arora et al. 2020). For those countries with large areas, the land $C$ sink can be large and offset a substantial proportion of the anthropogenic emissions. For example, in this study, among the four top emitter regions identified in the results by Friedlingstein et al. (2019), USA and China can sequester 9.6 and 4.5 Pg C, respectively by 2050 in their terrestrial ecosystems (Fig. 3 ), which can contribute to realize their reduction target 
for mitigating climate change. Federal lands across the conterminous USA will store $19.4 \%$ more $\mathrm{C}$ in 2050 than in 2005, with forests and grasslands gaining $C$ from 2006 to 2050 at a rate of 620 and $228 \mathrm{~kg} \mathrm{C} \mathrm{ha}^{-1}$ year $^{-1}$, respectively, but shrublands losing $\mathrm{C}$ ( $\mathrm{C}$ sources) at a rate of $13 \mathrm{~kg} \mathrm{C} \mathrm{ha}^{-1}$ year $^{-1}$ (Tan et al. 2015). The $C$ sequestration potential by federal lands in the conterminous USA in the future depends not only on the footprint of individual ecosystems but also on each federal agency's land use and management (Tan et al. 2015). The estimated ecosystem $C$ sink by evergreen needle-leaved forests in China increased rapidly with age, reached peak value of $0.45 \mathrm{~kg} \mathrm{C} \mathrm{m}^{-2}$ year $^{-1}$ at age of 22 years, and decreased gradually after that (Zhou et al. 2015). The highest $C$ sink efficiency (i.e., $C$ sink per unit NPP) of these evergreen needle-leaved forests occurred when forest age was between 11 and 43 years.

\section{Components that control land carbon sink}

The transient traceability framework allows us to quantify not only the land $\mathrm{C}$ sink of different countries but also the relative contributions of the involving processes, including production-driven change, turnover-driven change, interaction between production-driven change and turnover-driven change, and the change in instantaneous $\mathrm{C}$ storage potential. Among these four components, production-driven change accounts for the largest proportion of the $\mathrm{C}$ sink (Fig. 4). The second important component is turnover-driven change; and then the third one is change in instantaneous $\mathrm{C}$ storage potential. The interaction between production-driven change and turnover-driven change accounts for the least to $\mathrm{C}$ sink.

Carbon stored in terrestrial ecosystems is not only determined by how much $\mathrm{C}$ enters the ecosystem but also determined by how long $\mathrm{C}$ will stay in that system, with the former being known as NPP and the latter as $\mathrm{C}$ residence time. NPP is usually high in tropical regions and low in high latitude (Todd-Brown et al. 2013). Rising $\mathrm{CO}_{2}$ in atmosphere favorites NPP, which is well known as $\mathrm{CO}_{2}$ fertilization. The fertilization of $\mathrm{CO}_{2}$ on NPP, including both aboveground NPP (ANPP) and belowground NPP (BNPP), has been extensively demonstrated in manipulative experiments with elevated $\mathrm{CO}_{2}$ conducted in dozens of ecosystems (Song et al. 2019). Models also consistently simulate the fertilization of $\mathrm{CO}_{2}$ with a multiple model mean for carbonconcentration feedback parameter $\beta$ being $0.92 \mathrm{Pg} \mathrm{C}$ $\mathrm{ppm}^{-1}$ (Arora et al. 2013). As a result of $\mathrm{CO}_{2}$ fertilization, cumulative net land $\mathrm{C}$ sink over the period 1959 to 2010 is overwhelmingly contributed by atmospheric $\mathrm{CO}_{2}$, especially for tropics and extratropics (Huntzinger et al. 2017). Global NPP will keep increasing with time till 2100 because of rising $\mathrm{CO}_{2}$ (Friend et al. 2013)
Changes in precipitation have profound impacts on NPP. Increased precipitation usually enhances NPP and decreased precipitation reduces NPP, with ANPP being more sensitive than BNPP (Wilcox et al. 2017; Song et al. 2019). However, the sensitivity of ANPP to precipitation change would be saturating, likely driven by ANPP responses to extreme precipitation (Knapp et al. 2017; Wilcox et al. 2017). Primary production has been found to be most sensitive to precipitation in dryland and grassland ecosystems (Maurer et al. 2020). The trend and interannual variability of the global land C sink are dominated by semi-arid ecosystems where variations in precipitation and temperature strongly regulate ecosystem C balance (Ahlström et al. 2015).

Climate warming, however, has varied effects on NPP. Earth system models involved in CMIP5 simulate negative effects of warming on land $\mathrm{C}$ fluxes, with the multiple model mean for carbon-climate feedback parameter $\gamma$ of $-58.4 \mathrm{Pg} \mathrm{C}^{\circ} \mathrm{C}^{-1}$ (Arora et al. 2013). In a recent synthesis of the manipulative experiments of warming in the world, NPP and ANPP both remain unaltered but BNPP is slightly increased by warming (Song et al. 2019). In contrast, Wu et al. (2011) concluded that experimental warming stimulates NPP in another global synthesis with 85 studies. In a 13-year field warming experiment in a tallgrass prairie in Oklahoma, USA, warming consistently increases ANPP and BNPP, and the increased ANPP and BNPP are positively correlated with the proportion of ANPP contributed by $\mathrm{C}_{3}$ forbs $(\mathrm{Xu}$ et al. 2015).

Observational data and model simulations both show that $\mathrm{C}$ residence time is strongly dependent on temperature, that is, longer in colder regions than in warmer regions, with tundra and boreal forests having longest $C$ residence time than other terrestrial ecosystems (Carvalhais et al. 2014). Consistent with the relationship between $\mathrm{C}$ residence time and temperature, climate warming has been demonstrated to stimulate decomposition and therefore shorten $\mathrm{C}$ residence time, especially in cold regions (Friend et al. 2013; Tian et al. 2015). However, the widely accepted relationship between $\mathrm{C}$ residence time and warming may not hold true when accounting for changes in $C$ age structure and composition of respired C as found by Lu et al. (2018). In their study, warming can cause an increase in global $\mathrm{C}$ residence time due to the depletion of fast-turnover $\mathrm{C}$ pool and accompanied changes in compartment $C$ age structures.

Carbon residence time has a strong association with precipitation in the observation-based data set, which is surprising, but the pattern is not well reproduced by those CMIP5 models, highlighting that the hydrological cycle could be more important in affecting $\mathrm{C}$ cycle than it is represented in model simulations (Carvalhais et al. 2014). 
Rising atmospheric $\mathrm{CO}_{2}$ and $\mathrm{N}$ deposition help shorten residence time of soil $\mathrm{C}$ (Tian et al. 2015). The decreased ecosystem $\mathrm{C}$ residence time under elevated $\mathrm{CO}_{2}$ might be a result of replenishment of $\mathrm{C}$ into fast turnover $\mathrm{C}$ pool and subsequent decrease in compartment $\mathrm{C}$ age structure (Lu et al. 2018). A recent study with a global land surface model indicates that ecosystem $\mathrm{C}$ residence time has been reduced from 74 years in the 1860 s to 64 years in the 2000 s, due mainly to land use change and climate change (Wu et al. 2020). For soil C, however, land use change can bring either increased or decreased residence time of soil C (Tian et al. 2015). Predicted vegetation $C$ residence times under future $\mathrm{CO}_{2}$ and climate are increased, decreased, or stable, depending on different regions and due to changes in tree mortality and composition of vegetation types (Friend et al. 2013).

Conclusions on the relative importance of NPP and C residence time in determining land $C$ storage vary with different $\mathrm{C}$ pools. Vegetation $\mathrm{C}$ storage is determined more by $C$ residence time than NPP (Friend et al. 2013; Jiang et al. 2015). For soil C storage simulated by 11 ESMs in CMIP5, NPP and soil temperature explain much of the spatial variations in soil $C$ (Todd-Brown et al. 2013). As for ecosystem $C$ storage, more than half of land $C$ storage $(\sim 60 \%)$ is determined by ecosystem baseline residence time (Zhou et al. 2021).

Factors controlling changes in $\mathrm{C}$ storage, that is, $\mathrm{C}$ sink or source, might be different from those controlling transient $\mathrm{C}$ storage. The domination of productivitydriven changes (i.e., $\triangle \mathrm{NPP} \times \tau_{0}$ in this study) over turnover-driven changes (i.e., $\Delta \tau \times \mathrm{NPP}_{0}$ in this study) in controlling land $C$ pool changes has been detected by Koven et al. (2015) for both live C pools and dead C pools. This is understandable from mathematical perspective because turnover time is usually $0-48$ years and NPP is $0-2 \mathrm{~kg} \mathrm{C} \mathrm{m}^{-2}$ year $^{-1}$ (Koven et al. 2015). However, less control of turnover-driven change compared to productivity-driven change on $\mathrm{C}$ pool changes in response to the imposed forcings may result from the lack of process representation behind the changing turnover times, such as allocation and mortality for live $\mathrm{C}$ pool; and permafrost, microbial dynamics, and mineral stabilization for dead C pool (Koven et al. 2015).

While the contributions by the changes in instantaneous C storage potential, $X_{p}$, is not much, it can help bring $14.5 \%$ of $C$ sink. The instantaneous $C$ storage potential, $X_{p}$, is potential C sequestration restricted otherwise by environmental factors and other factors such as disturbances (Luo et al. 2017). Our results imply that if we manage our terrestrial ecosystems to the best conditions for the ecosystems, the ecosystems can store $14.5 \%$ more C. The proportion of instantaneous $\mathrm{C}$ storage potential in simulated global transient land $\mathrm{C}$ storage by 7 CMIP6 ESMs is $4.5 \%$ (Zhou et al. 2021), but its contributions in $\mathrm{C}$ sink has been amplified by 3 times. Accounting for only $7.9 \%$ of land C sink, the interaction between production-driven change and turnover-driven change (i.e., $\Delta \mathrm{NPP} \times \Delta \tau$ ) represents the interaction between change in NPP and change in C residence time. Our results demonstrate that change in $\mathrm{NPP}$ and change in $\mathrm{C}$ residence time are interactive in determining $\mathrm{C}$ sink.

In most previous studies that investigated the role of $\mathrm{C}$ residence time, a steady-state assumption has been applied, in which $\mathrm{C}$ residence time is derived by $\mathrm{C}$ storage divided by $\mathrm{C}$ inputs, GPP or NPP. This can bring significant bias in estimating ecosystem residence time ( $\mathrm{Lu}$ et al. 2018). The transient traceability framework allows us to disaggregate the individual components of land $\mathrm{C}$ sink of different countries, which eradicates the bias rooted in the steady-state assumption in $\mathrm{C}$ residence time. Due to the challenge to apply the full transient traceability framework to CMIP5 model outputs (Jiang et al. 2017), we are not able to further decompose $C$ sink into more specific $\mathrm{C}$ processes in this analysis. In the future, with more detailed information of those models, we may decompose $\mathrm{C}$ sink of different countries further and can thus know how individual $\mathrm{C}$ processes regulate land $\mathrm{C}$ sink better. Finally, as acknowledged by Koven et al. (2015), CMIP5 models may have some fundamental bias as reflected by the large uncertainty in the simulations across CMIP5 models shown both in this analysis and in many previous studies, which is a major challenge in predicting land carbon dynamics. To eliminate any bias related to selections of individual models, as a common practice in analyzing model results, we used the means of multiple models instead of results of any single model to represent the best model simulation results. Even though the use of the multiple model means to best represent the CMIP5 model simulation results in this analysis, the uncertainty across these CMIP5 models should be taken into account and needs to be carefully evaluated when making policies.

\section{Conclusions}

Our analysis of CMIP5 results suggests that most areas in the world will act as land $C$ sink by the middle of the twenty-first century under RCP8.5, especially in tropical and tundra regions. The top 20 countries with the highest $\mathrm{C}$ sink can sequester $62.1 \mathrm{Pg} \mathrm{C}$ in total, with Russia, Canada, USA, China, and Brazil sequestering the most and collectively accounting for three quarters of the total $\mathrm{C}$ sequestrated by the top 20 countries. Among the four traceable components of land $\mathrm{C}$ sink, production-driven change contributes the most, approximately half, highlighting the joint determinations of land $\mathrm{C}$ sink by change in NPP and inherent $C$ residence time of the countries. Turnover-driven change is the second largest component of land $\mathrm{C}$ sink, which indicates that original 
ecosystem NPP and change in C residence time also play a relative important role for terrestrial ecosystems to gain C. Better management of the terrestrial ecosystems can also help realize the maximal land $C$ sink while the change in instantaneous $\mathrm{C}$ storage potential, $X_{p}$, contributes a small proportion of $\mathrm{C}$ sink. Overall, land $\mathrm{C}$ sink from the terrestrial ecosystems can offset a substantial proportion of greenhouse-gas emissions, which should be better accounted in the future agreements by the United Nations Framework Convention on Climate Change.

\section{Abbreviations \\ C: Carbon; CMIP5: Coupled Model Intercomparison Project Phase 5; COP: Conference of the Parties; ESM: Earth system models; N: Nitrogen; NEE: Net ecosystem exchange; NEP: Net ecosystem production; NPP: Net primary production; RCP: Representative concentration pathway; UNFCCC: United Nations Framework Convention on Climate Change}

\section{Acknowledgements}

We thank Dr. Sha Zhou for sharing the code in their paper and Ning Wei for discussions on the results. We acknowledge the World Climate Research Programme's Working Group on Coupled Modeling, which is responsible for CMIP, and we thank the modeling groups (listed in Table 1) for producing and making their model outputs available.

\section{Authors' contributions}

$L, J L$, and $Y L$ designed this study. $L J$ and $X L$ conducted the analysis. All authors contributed to the interpretation and discussion of the results. LJ wrote the first draft and all other authors read, revised, and approved the final manuscript.

\section{Funding}

This work was supported by the National Science Foundation Grants (DEB, 1655499, 2017884), US Department of Energy (DE-SC0020227), and the subcontracts 4000158404 and 4000161830 from Oak Ridge National Laboratory (ORNL) to the Northern Arizona University.

\section{Availability of data and materials}

The CMIP5 data used in this study is available through the Earth System Grid Federation (ESGF): http://esgf-node.llnl.gov/. The data for the figures in this study is available at the authors' website: http://www2.nau.edu/luo-lab/download.

\section{Declarations}

Ethics approval and consent to participate

Not applicable.

\section{Consent for publication}

Not applicable.

\section{Competing interests}

The authors declare that they have no competing interests.

\section{Author details}

${ }^{1}$ Center for Ecosystem Science and Society, Northern Arizona University, Flagstaff, AZ 86011, USA. ² College of Grassland Science and Technology, China Agricultural University, Beijing 100083, China. ${ }^{3}$ School of Atmospheric Sciences, Sun Yat-sen University, Guangzhou 510275, Guangdong, China. ${ }^{4}$ Computational Sciences \& Engineering Division and Climate Change Science Institute, Oak Ridge National Laboratory, Oak Ridge, TN 37831, USA. ${ }^{5}$ Department of Biological Sciences, Northern Arizona University, Flagstaff, AZ 86011, USA.
Received: 24 February 2021 Accepted: 26 July 2021

Published online: 14 September 2021

\section{References}

Adachi Y, Yukimoto S, Deushi M, Obata A, Nakano H, Tanaka TY, Hosaka M, Sakami T, Yoshimura H, Hirabara M, Shindo E, Tsujino H, Mizuta R, Yabu S, Koshiro T, Ose T, Kitoh A (2013) Basic performance of a new earth system model of the Meteorological. Research Institute (MRI-ESM1). Papers in Meteorology and Geophysics, 64:1-19. https://doi.org/10.2467/mripapers.64.1.

Ahlström A, Raupach MR, Schurgers $G$ et al (2015) The dominant role of semiarid ecosystems in the trend and variability of the land $\mathrm{CO}_{2}$ sink. Science 348(6237):895-899. https://doi.org/10.1126/science.aaa1668

Akaev AA (2017) From Rio to Paris: achievements, problems, and prospects in the struggle against climate change. Her Russ Acad Sci 87(4):299-309. https://doi. org/10.1134/S1019331617040013

Arora V, Boer GJ (2010) Uncertainties in the 20th century carbon budget associated with land use change. Glob Chang Biol 16(12):3327-3348. https:// doi.org/10.1111/j.1365-2486.2010.02202.x

Arora V, Boer GJ, Friedlingstein P, et al (2013) Carbon-concentration and carbonclimate feedbacks in CMIP5 earth system models. J Clim 26(15):5289-5314. https://doi.org/10.1175/JCLI-D-12-00494.1

Arora VK, Katavouta A, Williams RG, Jones CD, Brovkin V, Friedlingstein P, Schwinger J, Bopp L, Boucher O, Cadule P, Chamberlain MA, Christian JR, Delire C, Fisher RA, Hajima T, llyina T, Joetzjer E, Kawamiya M, Koven CD, Krasting JP, Law RM, Lawrence DM, Lenton A, Lindsay K, Pongratz J, Raddatz T, Séférian R, Tachiiri K, Tjiputra JF, Wiltshire A, Wu T, Ziehn T (2020) Carbonconcentration and carbon-climate feedbacks in CMIP6 models and their comparison to CMIP5 models. Biogeosciences 17(16):4173-4222. https://doi. org/10.5194/bg-17-4173-2020

Bonan GB (1996) A Land Surface Model (LSM Version 1.0) for ecological, hydrological and atmospheric studies: technical description and user's guide (NCAR Technical Note), No. 417. National Center for Atmospheric Research, Boulder

Brovkin V, Raddatz T, Reick CH, Claussen M, Gayler V (2009) Global biogeophysical interactions between forest and climate. Geophys Res Lett 36:L07405

Carvalhais N, Forkel M, Khomik M, Bellarby J, Jung M, Migliavacca M, Mu M, Saatchi S, Santoro M, Thurner M, Weber U, Ahrens B, Beer C, Cescatti A, Randerson JT, Reichstein M (2014) Global covariation of carbon turnover times with climate in terrestrial ecosystems. Nature 514(7521):213-217. https://doi.org/10.1038/nature13731

Chazdon RL, Broadbent EN, Rozendaal DMA, Bongers F, Zambrano AMA, Aide TM, Balvanera P, Becknell JM, Boukili V, Brancalion PHS, Craven D, AlmeidaCortez JS, Cabral GAL, de Jong B, Denslow JS, Dent DH, DeWalt SJ, Dupuy JM, Durán SM, Espírito-Santo MM, Fandino MC, César RG, Hall JS, HernándezStefanoni JL, Jakovac CC, Junqueira AB, Kennard D, Letcher SG, Lohbeck M, Martínez-Ramos M, Massoca P, Meave JA, Mesquita R, Mora F, Muñoz R, Muscarella R, Nunes YRF, Ochoa-Gaona S, Orihuela-Belmonte E, Peña-Claros M, Pérez-García EA, Piotto D, Powers JS, Rodríguez-Velazquez J, Romero-Pérez IE, Ruíz J, Saldarriaga JG, Sanchez-Azofeifa A, Schwartz NB, Steininger MK, Swenson NG, Uriarte M, van Breugel M, van der Wal H, Veloso MDM, Vester H, Vieira ICG, Bentos TV, Williamson GB, Poorter L (2016) Carbon sequestration potential of second-growth forest regeneration in the Latin American tropics. Sci Adv 2(5):e1501639. https:/doi.org/10.1126/sciadv.1501639

Collins WJ, Bellouin N, Doutriaux-Boucher M, Gedney N, Halloran P, Hinton T, Hughes J, Jones CD, Joshi M, Liddicoat S, Martin G, O'Connor F, Rae J, Senior C, Sitch S, Totterdell I, Wiltshire A, Woodward S (2011) Development and evaluation of an Earth-System model - HadGEM2. Geosci Model Dev 4(4): 1051-1075. https://doi.org/10.5194/gmd-4-1051-2011

Cox PM (2001) Description of the TRIFFID dynamic global vegetation model, technical note 24. Hadley Centre, Met Office

Dai YJ, Zeng X, Dickinson RE, Baker I, Bonan GB, Bosilovich MG, Denning AS, Dirmeyer PA, Houser PR, Niu G, Oleson KW, Schlosser CA, Yang ZL (2003) The common land model. Bull Am Meteorol Soc 84(8):1013-1023. https://doi. org/10.1175/BAMS-84-8-1013

Dai YJ, Dickinson RE, Wang YP (2004) A two-big-leaf model for canopy temperature, photosynthesis, and stomatal conductance. J Clim 17(12):22812299. https://doi.org/10.1175/1520-0442(2004)017<2281:ATMFCT>2.0.CO;2

Dufresne J, Foujols M, Denvil S et al (2013) Climate change projections using the IPSL-CM5 Earth System Model: from CMIP3 to CMIP5. Clim Dyn 40(9-10): 2123-2165. https://doi.org/10.1007/s00382-012-1636-1 
Dunne JP, John JG, Shevliakova E et al (2013) GFDL's ESM2 global coupled climate-carbon earth system models. Part II: carbon system formulation and baseline simulation characteristics. J Clim 26:2247-2267

Espinosa M, Acuna E, Cancino J, Munoz F, Perry DA (2005) Carbon sink potentia of radiata pine plantations in Chile. Forestry 78(1):11-19. https://doi.org/10.1 093/forestry/cpi002

Friedlingstein P, Cox P, Betts R, Bopp L, von Bloh W, Brovkin V, Cadule P, Doney S, Eby M, Fung I, Bala G, John J, Jones C, Joos F, Kato T, Kawamiya M, Knorr W, Lindsay K, Matthews HD, Raddatz T, Rayner P, Reick C, Roeckner E, Schnitzler KG, Schnur R, Strassmann K, Weaver AJ, Yoshikawa C, Zeng N (2006) Climate-carbon cycle feedback analysis: results from the $C^{4}$ MIP model intercomparison. J Clim 19(14):3337-3353. https://doi.org/10.1175/JCLI3800.1

Friedlingstein P, Meinshausen M, Arora VK, Jones CD, Anav A, Liddicoat SK, Knutti $R$ (2014) Uncertainties in CMIP5 climate projections due to carbon cycle feedbacks. J Clim 27(2):511-526. https://doi.org/10.1175/JCLI-D-12-00579.1

Friedlingstein P, Jones MW, O'Sullivan M et al (2019) Global Carbon Budget 2019. Earth Syst Sci Data 11(4):1783-1838. https://doi.org/10.5194/essd-11-1783-2019

Friend AD, Lucht W, Rademacher TT et al (2013) Carbon residence time dominates uncertainty in terrestrial vegetation responses to future climate and atmospheric $\mathrm{CO}_{2}$. PNAS 111:3280-3285

Grassi G, House J, Dentener F, Federici S, den Elzen M, Penman J (2017) The key role of forests in meeting climate targets requires science for credible mitigation. Nat Clim Change 7(3):220-226. https://doi.org/10.1038/nclimate3227

Grelle A, Aronsson P, Weslien P, Klemedtsson L, Lindroth A (2007) Large carbonsink potential by Kyoto forests in Sweden-a case study on willow plantations. Tellus B Chem Phys Meteorol 59(5):910-918. https://doi.org/1 0.1111/j.1600-0889.2007.00299.x

Hararuk O, Xia JY, Luo YQ (2014) Evaluation and improvement of a global land model against soil carbon data using a Bayesian Markov chain Monte Carlo method. J Geophys Res Biogeosci 119(3):403-417. https://doi.org/10.1002/2 013JG002535

Huntzinger DN, Michalak AM, Schwalm C, Ciais P, King AW, Fang Y, Schaefer K, Wei Y, Cook RB, Fisher JB, Hayes D, Huang M, Ito A, Jain AK, Lei H, Lu C, Maignan F, Mao J, Parazoo N, Peng S, Poulter B, Ricciuto D, Shi X, Tian H, Wang W, Zeng N, Zhao F (2017) Uncertainty in the response of terrestrial carbon sink to environmental drivers undermines carbon-climate feedback predictions. Sci Rep 7(1):4765. https://doi.org/10.1038/s41598-017-03818-2

IPCC (2018) Global Warming of $1.5^{\circ} \mathrm{C}$

Ji J, Huang M, Li K (2008) Prediction of carbon exchange between China terrestrial ecosystem and atmosphere in 21st century. Sci China Ser D Earth Sci 51(6):885-898. https://doi.org/10.1007/s11430-008-0039-y

Ji D, Wang L, Feng J, Wu Q, Cheng H, Zhang Q, Yang J, Dong W, Dai Y, Gong D, Zhang RH, Wang X, Liu J, Moore JC, Chen D, Zhou M (2014) Description and basic evaluation of BNU-ESM version 1. Geosci Model Dev 7(5):2039-2064. https://doi.org/10.5194/gmd-7-2039-2014

Jiang L, Yan Y, Hararuk O, Mikle N, Xia J, Shi Z, Tjiputra J, Wu T, Luo Y (2015) Scale-dependent performance of CMIP5 Earth system models in simulating terrestrial vegetation carbon. J Clim 28(13):5217-5232. https://doi.org/10.11 75/JCLI-D-14-00270.1

Jiang LF, Shi Z, Xia JY, Liang JY, Lu XJ, Wang Y, Luo YQ (2017) Transient traceability analysis of land carbon storage dynamics: procedures and its application to two forest ecosystems. J Adv Model Earth Syst 9(8):2822-2835. https://doi.org/10.1002/2017MS001004

Jones CD, Hughes JK, Bellouin N, Hardiman SC, Jones GS, Knight J, Liddicoat S, O'Connor FM, Andres RJ, Bell C, Boo KO, Bozzo A, Butchart N, Cadule P, Corbin KD, Doutriaux-Boucher M, Friedlingstein P, Gornall J, Gray L, Halloran PR, Hurtt G, Ingram WJ, Lamarque JF, Law RM, Meinshausen M, Osprey S, Palin EJ, Parsons Chini L, Raddatz T, Sanderson MG, Sellar AA, Schurer A Valdes P, Wood N, Woodward S, Yoshioka M, Zerroukat M (2011) The HadGEM2-ES implementation of CMIP5 centennial simulations. Geosci Model Dev 4(3):543-570. https://doi.org/10.5194/gmd-4-543-2011

Jones C, Robertson E, Arora V, Friedlingstein P, Shevliakova E, Bopp L, Brovkin V, Hajima T, Kato E, Kawamiya M, Liddicoat S, Lindsay K, Reick CH, Roelandt C, Segschneider J, Tjiputra J (2013) Twenty-first-century compatible $\mathrm{CO}_{2}$ emissions and airborne fraction simulated by CMIP5 earth system models under four representative concentration pathways. J Clim 26(13):4398-4413. https://doi.org/10.1175/JCLI-D-12-00554.1

Kaul M, Mohren GMJ, Dadhwal VK (2010) Carbon storage and sequestration potential of selected tree species in India. Mitig Adapt Strat Gl 15(5):489-510. https://doi.org/10.1007/s11027-010-9230-5
Knapp AK, Ciais P, Smith MD (2017) Reconciling inconsistencies in precipitationproductivity relationships: implications for climate change. New Phytol 214(1):41-47. https://doi.org/10.1111/nph.14381

Kongsager R, Napier J, Mertz O (2013) The carbon sequestration potential of tree crop plantations. Mitig Adapt Strat Gl 18(8):1197-1213. https://doi.org/10.1 007/s11027-012-9417-z

Koven CD, Chambers JQ, Georgiou K, Knox R, Negron-Juarez R, Riley WJ, Arora VK, Brovkin V, Friedlingstein P, Jones CD (2015) Controls on terrestrial carbon feedbacks by productivity versus turnover in the CMIP5 Earth System Models. Biogeosciences 12(17):5211-5228. https://doi.org/10.5194/bg-12-5211-2015

Krinner G, Viovy N, de Noblet-Ducoudré N, Ogée J, Polcher J, Friedlingstein P, Ciais P, Sitch S, Prentice IC (2005) A dynamic global vegetation model for studies of the coupled atmosphere-biosphere system. Global Biogeochem Cycles 19:GB1015

Lawrence DM, Oleson KW, Flanner MG et al (2011) Parameterization improvements and functional and structural advances in version 4 of the community land model. J Adv Model Earth Syst 3:M03001

Le Quéré C, Andrew RM, Friedlingstein P et al (2018) Global Carbon Budget 2017. Earth Syst Sci Data 10(1):405-448. https://doi.org/10.5194/essd-10-405-2018

Le Quéré C, Jackson RB, Jones MW et al (2020) Temporary reduction in daily global $\mathrm{CO}_{2}$ emissions during the COVID-19 forced confinement. Nat Clim Change 10(7):647-653.https://doi.org/10.1038/s41558-020-0797-x

Lu XJ, Wang Y-P, Luo YQ, Jiang LF (2018) Ecosystem carbon transit versus turnover times in response to climate warming and rising atmospheric $\mathrm{CO}_{2}$ concentration. Biogeosciences 15(21):6559-6572. https://doi.org/10.5194/ bg-15-6559-2018

Luo Y, Su B, Currie WS et al (2004) Progressive nitrogen limitation of ecosystem responses to rising atmospheric $\mathrm{CO}_{2}$ concentration. BioScience 54(8):731739. https://doi.org/10.1641/0006-3568(2004)054[0731:PNLOER]2.0.CO;2

Luo YQ, Shi Z, Lu XJ, Xia J, Liang J, Jiang J, Wang Y, Smith MJ, Jiang L, Ahlström A, Chen B, Hararuk O, Hastings A, Hoffman F, Medlyn B, Niu S, Rasmussen M, Todd-Brown K, Wang YP (2017) Transient dynamics of terrestrial carbon storage: mathematical foundation and numeric examples. Biogeosciences 14(1):145-161. https://doi.org/10.5194/bg-14-145-2017

Maurer GE, Hallmark AJ, Brown RF, Sala OE, Collins SL (2020) Sensitivity of primary production to precipitation across the United States. Ecol Lett 23(3):527-536. https://doi.org/10.1111/ele.13455

Niu XZ, Duiker SW (2006) Carbon sequestration potential by afforestation of marginal agricultural land in the Midwestern US. Forest Ecol Manag 223(1-3): 415-427. https://doi.org/10.1016/j.foreco.2005.12.044

Raddatz TJ, Reick CH, Knorr W, Kattge J, Roeckner E, Schnur R, Schnitzler K-G, Wetzel P, Jungclaus J (2007) Will the tropical land biosphere dominate the climate-carbon cycle feedback during the twenty-first century? Clim Dyn 29(6):565-574. https://doi.org/10.1007/s00382-007-0247-8

Reick CH, Raddatz T, Brovkin V, Gayler V (2013) Representation of natural and anthropogenic land cover change in MPI-ESM. J Adv Model Earth Syst 5(3): 459-482. https://doi.org/10.1002/jame.20022

Sato H, Itoh A, Kohyama T (2007) SEIB-DGVM: A new dynamic global vegetation model using a spatially explicit individual-based approach. Ecol Model 200(34):279-307. https://doi.org/10.1016/j.ecolmodel.2006.09.006

Shevliakova E, Pacala SW, Malyshev S, Hurtt GC, Milly PCD, Caspersen JP, Sentman LT, Fisk JP, Wirth C, Crevoisier C (2009) Carbon cycling under 300 years of land use change: importance of the secondary vegetation sink. Global Biogeochem Cycles 23:GB2022

Smith P, Andren O, Karlsson T, Perala P, Regina K, Rounsevell M, van Wesemael B (2005) Carbon sequestration potential in European croplands has been overestimated. Glob Chang Biol 11(12):2153-2163. https://doi.org/10.1111/ j.1365-2486.2005.01052.x

Song J, Wan S, Piao S, Knapp AK, Classen AT, Vicca S, Ciais P, Hovenden MJ, Leuzinger S, Beier C, Kardol P, Xia J, Liu Q, Ru J, Zhou Z, Luo Y, Guo D, Adam Langley J, Zscheischler J, Dukes JS, Tang J, Chen J, Hofmockel KS, Kueppers LM, Rustad L, Liu L, Smith MD, Templer PH, Quinn Thomas R, Norby RJ, Phillips RP, Niu S, Fatichi S, Wang Y, Shao P, Han H, Wang D, Lei L, Wang J, Li X, Zhang Q, Li X, Su F, Liu B, Yang F, Ma G, Li G, Liu Y, Liu Y, Yang Z, Zhang K, Miao Y, Hu M, Yan C, Zhang A, Zhong M, Hui Y, Li Y, Zheng M (2019) A meta-analysis of 1,119 manipulative experiments on terrestrial carbon-cycling responses to global change. Nat Ecol Evol 3(9):1309-1320. https://doi.org/1 0.1038/s41559-019-0958-3

Tan ZX, Lal R (2005) Carbon sequestration potential estimates with changes in land use and tillage practice in Ohio, USA. Agric Ecosyst Environ 111(1-4): 140-152. https://doi.org/10.1016/j.agee.2005.05.012 
Tan ZX, Liu SG, Sohl TL, Wu YP, Young CJ (2015) Ecosystem carbon stocks and sequestration potential of federal lands across the conterminous United States. PNAS 112(41):12723-12728. https://doi.org/10.1073/pnas.1512542112

Taylor KE, Balaji V, Hankin S, Juckes M, Lawrence B (2010) CMIP5 and AR5 data reference syntax (DRS), Version 0.25. http://cmip-pcmdi.Inl.gov/cmip5/docs/ cmip5 data reference syntax v0-25_clean.pdf

Taylor KE, Stouffer RJ, Meehl G (2012) An overview of CMIP5 and the experiment design. Bull Am Meteorol Soc 93(4):485-498. https://doi.org/10.1175/BAMSD-11-00094.1

The HadGEM2 Development Team (2011) The HadGEM2 family of Met Office Unified Model climate configurations. Geosci Model Dev 4(3):723-757. https://doi.org/10.5194/gmd-4-723-2011

The NCAR Command Language (Version 6.6.2) [Software] (2019) Boulder. UCAR/ NCAR/CISL/TDD, Colorado https://doi.org/10.5065/D6WD3XH5

Thornton PE, Zimmermann NE (2007) An improved canopy integration scheme for a land surface model with prognostic canopy structure. J Clim 20(15): 3902-3923. https://doi.org/10.1175/JCLI4222.1

Thornton PE, Lamarque J-F, Rosenbloom NA, Mahowald NM (2007) Influence of carbon-nitrogen cycle coupling on land model response to $\mathrm{CO}_{2}$ fertilization and climate variability. Global Biogeochem Cycles 21:GB4018

Thornton PE, Doney SC, Lindsay K, Moore JK, Mahowald N, Randerson JT, Fung I, Lamarque J-F, Feddema JJ, Lee Y-H (2009) Carbon-nitrogen interactions regulate climate-carbon cycle feedbacks: results from an atmosphere-ocean general circulation model. Biogeosciences 6(10):2099-2120. https://doi.org/1 0.5194/bg-6-2099-2009

Tian H, Lu C, Yang J, Banger K, Huntzinger DN, Schwalm CR, Michalak AM, Cook R, Ciais P, Hayes D, Huang M, Ito A, Jain AK, Lei H, Mao J, Pan S, Post WM, Peng S, Poulter B, Ren W, Ricciuto D, Schaefer K, Shi X, Tao B, Wang W, Wei Y, Yang Q, Zhang B, Zeng N (2015) Global patterns and controls of soil organic carbon dynamics as simulated by multiple terrestrial biosphere models: Current status and future directions. Global Biogeochem Cycles 29(6):775-792. https://doi.org/10.1002/2014GB005021

Tjiputra JF, Roelandt C, Bentsen M, Lawrence DM, Lorentzen T, Schwinger J, Seland $\varnothing$, Heinze C (2013) Evaluation of the carbon cycle components in the Norwegian Earth System Model (NorESM). Geosci Model Dev 6(2):301-325. https://doi.org/10.5194/gmd-6-301-2013

Todd-Brown KEO, Randerson JT, Post WM, Hoffman FM, Tarnocai C, Schuur EAG, Allison SD (2013) Causes of variation in soil carbon predictions from CMIP5 Earth system models and comparison with observations. Biogeosciences 10(3):1717-1736. https://doi.org/10.5194/bg-10-1717-2013

Volodin EM (2007) Atmosphere-ocean general circulation model with the carbon cycle. Izv Acad Sci USSR Atmos Oceanic Phys 43(3):266-280. https://doi.org/1 $0.1134 /$ S0001433807030024

Watanabe S, Hajima T, Sudo K, Nagashima T, Takemura T, Okajima H, Nozawa T, Kawase H, Abe M, Yokohata T, Ise T, Sato H, Kato E, Takata K, Emori S, Kawamiya M (2011) MIROC-ESM 2010: model description and basic results of CMIP5-20c3m experiments. Geosci Model Dev 4(4):845-872. https://doi.org/1 $0.5194 / g m d-4-845-2011$

Wilcox KR, Shi Z, Gherardi LA, Lemoine NP, Koerner SE, Hoover DL, Bork E, Byrne KM, Cahill J Jr, Collins SL, Evans S, Gilgen AK, Holub P, Jiang L, Knapp AK, LeCain D, Liang J, Garcia-Palacios P, Peñuelas J, Pockman WT, Smith MD, Sun S, White SR, Yahdjian L, Zhu K, Luo Y (2017) Asymmetric responses of primary productivity to precipitation extremes: a synthesis of grassland precipitation manipulation experiments. Glob Chang Biol 23(10):4376-4385. https://doi.org/10.1111/gcb.13706

Wu Z, Dijkstra P, Koch GW, Peñuelas J, Hungate BA (2011) Responses of terrestrial ecosystems to temperature and precipitation change: a meta-analysis of experimental manipulation. Glob Chang Biol 17(2):927-942. https://doi.org/1 0.1111/j.1365-2486.2010.02302.x

Wu T, Li W, Ji J et al (2013) Global carbon budgets simulated by the Beijing Climate Center Climate System Model for the last century. J Geophys Res Atmos 118:1-22

Wu D, Piao S, Zhu D, Wang X, Ciais P, Bastos A, Xu X, Xu W (2020) Accelerated terrestrial ecosystem carbon turnover and its drivers. Glob Change Biol 26(9): 5052-5062. https://doi.org/10.1111/gcb.15224

Xu X, Shi Z, Li DJ, Zhou XH, Sherry RA, Luo YQ (2015) Plant community structure regulates responses of prairie soil respiration to decadal experimental warming. Glob Chang Biol 21(10):3846-3853. https://doi.org/10.1111/gcb.12940

Zhou T, Shi P, Jia G, Dai Y, Zhao X, Shangguan W, Du L, Wu H, Luo Y (2015) Agedependent forest carbon sink: estimation via inverse modeling. J Geophys Res Biogeosci 120(12):2473-2492. https://doi.org/10.1002/2015JG002943
Zhou S, Liang JY, Lu XJ, Li Q, Jiang L, Zhang Y, Schwalm CR, Fisher JB, Tjiputra J, Sitch S, Ahlström A, Huntzinger DN, Huang Y, Wang G, Luo Y (2018) Sources of uncertainty in modeled land carbon storage within and across three MIPs: Diagnosis with three new techniques. J Clim 31(7):2833-2851. https://doi. org/10.1175/JCLI-D-17-0357.1

Zhou J, Xia J, Wei N, Liu Y, Bian C, Bai Y, Luo Y (2021) A traceability analysis system for model evaluation on land carbon dynamics: design and applications. Ecol Process 10:12. https://doi.org/10.1186/s13717-021-00281-w

\section{Publisher's Note}

Springer Nature remains neutral with regard to jurisdictional claims in published maps and institutional affiliations.

\section{Submit your manuscript to a SpringerOpen ${ }^{\odot}$ journal and benefit from:}

- Convenient online submission

- Rigorous peer review

- Open access: articles freely available online

- High visibility within the field

- Retaining the copyright to your article

Submit your next manuscript at $\boldsymbol{\nabla}$ springeropen.com 